\title{
REVIEW OF RESULTS OF AGRO-PHOTOVOLTAIC SYSTEM IMPLEMENTATION IN AGRICULTURE
}

\author{
Vytautas Adomavicius \\ Kaunas University of Technology, Lithuania \\ vytautas.adomavicius@ktu.lt
}

\begin{abstract}
The article provides an overview of agro-photovoltaic systems already implemented and researched or tested in the world, describes the results of exploitation of such systems, their efficiency, benefits for agriculture, possibilities for further research, and for the development of green electricity production. Some information is also provided in order to show the viability of the development of photovoltaic power plants, their environmental friendliness, and their important role in halting climate change. The results of the researches of the globally implemented agro-photovoltaic systems show the indisputable efficiency of these systems and their obvious advantage over the traditional agricultural technologies. As the results of the research show, dual land exploitation for agriculture and electricity generation by agro-photovoltaic systems almost doubles the land use efficiency (up to $186 \%)$. Some suggestions are discussed for further researches of agro-photovoltaic systems. The history of implementation of agro-photovoltaic systems began less than 20 years ago. So far, now we have only a small group of leading countries in this area, but in most of the remaining countries, these systems are still unknown and untested. Therefore, the goal of this overview was to disclose the efficiency of the agro-photovoltaic systems, their viability, and to contribute to the dissemination of information in order to pave the way for acceleration of progress in this promising field of agriculture.
\end{abstract}

Keywords: horticulture, livestock, agro-photovoltaics, electricity, efficiency.

\section{Introduction}

In the electricity generation sector, there is constant competition on a global scale between different technologies according to many parameters. The aim of the competition is to reduce the price of electricity produced, improve the efficiency of the primary energy source utilisation, increase energy independence and reliability of electricity supply. Solar and wind power plants have already caught up with the cheapest fossil fuel power plants in terms of the price of electricity without subsidies. In addition, it is very important to take into consideration the ecological characteristics of electricity generation technologies. The absolute champions in this field are RES-based technologies.

Another type of competition appeared in rural areas for the land after the development of solar modules for electricity generation, which can be installed not only on roofs and water bodies, but also on the ground. However, the world does not have so much land suitable for farming. In addition, the price index of photovoltaic modules was still very high in the last decades of the last century. So, ecologically efficient but expensive photovoltaic technology for power production was initially not met friendly in rural areas, despite the fact that German scientists A. Goetzberger and A. Zastrow in 1981 proposed the concept of dual-use land - both for agricultural needs and for electricity generation using photovoltaic power plants (PVPP). This concept was published in their publication in 1982 [1].

Over time, the price index for solar modules dramatically fell down and reached a level that researchers became interested in the concept of dual land use again. In Japan, Prof. Akira Nagashima began experimenting in this area in 2003 [2]. After this, the prices of solar modules have continued to fall very rapidly and the operational efficiency of the modules has increased significantly. Conditions for the installation of PVPP and agro-photovoltaic systems (APVS) became attractive. Presently a group of leading countries has already performed a significant number of projects in the area of APVS, but there are many countries, where these systems are still unknown, untested, and unused.

The total power of the PVPP built per one year in the world presently is the highest among all electricity generation technologies. According to the data of the International Energy Agency (IEA) for $2020-2025$, together with the newly built wind farms presently they account for $80 \%$ of total annual capacity, leaving only about $20 \%$ for all other technologies [3]. Photovoltaic (PV) power plants are very suitable for installation in rural areas as well, especially when the concept of land double use is applied. Significant progress has been made over the last 15 years in the implementation of APVS. Solar power plants are now successfully combined with the cultivation of potatoes, many types of vegetables, flowers, herbs, plants, some spices, grapes, olives, and other species. When the soil areas are fenced, there can be kept geese, chicks, ducks, bees, sheep, deer, goats, cows, etc. 


\section{Materials and methods}

The material for this article has been searched on a global scale in various sources of information in articles of scientific journals, proceedings of scientific conferences, in scientific books, doctoral dissertations, in periodical online publications of universities and research institutes, and in other available sources of information. Part of the found information sources is presented in the references of this paper, where readers will find useful additional information on the APVS.

Conventional methods were used to overview the available information regarding the APVS. Selected information sources were studied and analysed, the most important information was summarized. After this, the main results of the study were described and discussion about the perspectives of development of dual land use in agriculture was presented. The main insights on the agro-photovoltaic systems were formulated and presented as the conclusions of the review.

\section{Results and discussion}

A review of available sources of information showed that photovoltaic arrays can be mounted on the roofs of greenhouses, over arable land, and on the surface of water bodies (floating PV arrays). Each case of APVS is more or less unique. Some examples of APVS adapted to different species and used for cultivation of crops or keeping livestock are described in Table 1. A greenhouse for the growing Welsh onions was built for research of APVS operation in Shimane Agricultural Technology Centre, Japan [4]. The PV array was installed on the top of the greenhouse. 30 panels of $24 \mathrm{~W}$ were used to form the PV array. Coverage of the greenhouse roof was not significant $-12.9 \%$. Straight-line and checkerboard layouts of the PV modules were tested on the roof of the greenhouse. The checkerboard layout option was better - the onions received more sunlight and the yield was better.

Two Canary Islands greenhouses for APVS research were built in 2017 in Agadir, Morocco [5]. The areas of both greenhouses were the same $-172 \mathrm{~m}^{2}$ each. $32 \mathrm{PV}$ modules of $100 \mathrm{~W}(3.2 \mathrm{~kW})$ were installed on the roof of the main greenhouse. They occupied $10 \%$ of the roof area. The second greenhouse was used as a control for the comparison of the research results and was free from PV modules. Tomatoes were grown in the both greenhouses, where eight crops were harvested per year. Comparison of the harvests in both greenhouses showed a slight advantage of the PV greenhouse about $105 \%$ against $100 \%$ in the control greenhouse. In addition, it was observed that there were slightly fewer tomatoes eating pests Tuta absoluta in the experimental PV greenhouse.

An interesting APVS for growing vegetables and producing electricity was developed by the Indian Institute CAZRI in Jodhpur, Rajasthan [6]. They found a way to make more efficient use of their system and additionally installed a system to collect rainwater running from the PV modules. The accumulated water was for additional watering of vegetables. The amount of rainwater harvested per year from the PV modules was $150 \mathrm{~m}^{3}$ per acre. The capacity of the installed PVPP was $105 \mathrm{~kW}$.

One of the simplest options for APVS is when solar modules are installed on the meadow and all available land around it is fenced. Free-range animals (sheep, goats, deer, cows, horses, etc.) or poultry (geese, ducks, chickens, turkeys, etc.) can be kept in the enclosure. In this case, only the height of the PV module elevation above the land surface may be relevant depending on the species of animals and on their behaviour. This type of APVS is already installed in many farms - in Benbole Farm, Wadebridge, Cornwall [7], in Newlands Farm, Axminster, Devon [7] (both in the UK), in Tsukuba, Ibaraki, Japan [2], in Princeton University solar field, New Jersey, USA [8] and elsewhere.

The well-known project APV-RESOLA was designed to explore the possibilities of growing vegetables and cereals under the PV arrays. The full programme of this project was implemented in Heggelbach, region Bodensee-Oberschwaben, Germany in the years 2015-2020 [2; 9]. Coordinator of this project was the Fraunhofer Institute for Solar Energy Systems (in German - Fraunhofer Institut für Solare Energiesysteme or shortly - Fraunhofer ISE). One of the studies listed in the project program was to check the possibility of growing potatoes on the same land area under the modules and in the spaces between the strings of modules of the PV array. Three plots of land of equal size (1 ha) with equal soil were selected for the research. Only potatoes were planted in one (control) plot of land. The PV array with solar modules mounted as usual was installed nearby on another control plot of land. The total capacity of the PV array was $194.4 \mathrm{~kW}$. The PV array with the same capacity $(194.4 \mathrm{~kW})$ was mounted and the potatoes were planted in the last experimental plot of land. However, the PV array was 
mounted differently in this case for the convenience of agricultural machinery (so that agricultural machines could pass under the PV modules). Once the potatoes were grown, they were harvested and weighed. Quantities of electricity produced in the experimental and control plots were also measured. Potato yields and electricity generated on control plots were equated to $100 \%$. Interesting results were obtained in the experimental dual-use land area: potato yield was $103 \%$, and electricity production $83 \%$. The efficiency of dual-use land area exploitation was $186 \%$.

Table 1

Already researched or practically tested APVS in the world

\begin{tabular}{|c|c|c|c|}
\hline APVS & Type of APVS & Parameters of the system & Benefits for agriculture \\
\hline $\begin{array}{c}\text { Shimane } \\
\text { Agricultural } \\
\text { Technology Center, } \\
\text { Japan }\end{array}$ & $\begin{array}{c}\text { PVPP and } \\
\text { greenhouse } \\
\text { Welsh onions } \\
{[4]}\end{array}$ & $\begin{array}{c}\text { Greenhouse } 84.6 \mathrm{~m}^{2} \\
\text { PV array of } 30 \text { modules } \\
\text { mounted in } 2007(720 \mathrm{~W}), \\
\text { covered } 12.9 \% \text { of roof. }\end{array}$ & $\begin{array}{l}\text { Electricity produced per } \\
\text { year - about } 800 \mathrm{kWh} . \\
\text { Crop of Welsh onions. }\end{array}$ \\
\hline $\begin{array}{c}\text { Agadir, } \\
\text { Morocco, } \\
\text { Atlantic coast }\end{array}$ & $\begin{array}{l}\text { PVPP and } \\
\text { tomatoes in one } \\
\text { greenhouse, only } \\
\text { tomatoes in control } \\
\text { greenhouse [5] }\end{array}$ & $\begin{array}{c}2 \text { Canarian greenhouses } \\
172+172 \mathrm{~m}^{2}, \text { height } 5 \mathrm{~m} . \\
\text { PV array } 3200 \mathrm{~W} \text { mounted } \\
\text { in } 2017 \text { covered } 10 \% \text { of } \\
\text { roof area. }\end{array}$ & $\begin{array}{l}8 \text { harvests were performed } \\
\text { in both greenhouses. } \\
\text { Average yield in the } \\
\text { photovoltaic greenhouse } \\
\text { was about 5-6\% higher. }\end{array}$ \\
\hline $\begin{array}{l}\text { Institute CAZRI, } \\
\text { Jodhpur, Rajasthan, } \\
\text { India }\end{array}$ & $\begin{array}{c}\text { PVPP and } \\
\text { vegetables of } \\
\text { various types } \\
{[6]}\end{array}$ & $\begin{array}{l}\text { Land area }-1 \text { ha, } \\
\text { PV power plant }-105 \mathrm{~kW} \\
\text { installed in } 2016 \text { with rain } \\
\text { water harvesting system for } \\
\text { supplemental irrigation }\end{array}$ & $\begin{array}{l}\text { Electricity produced per } \\
\text { year - about } 130 \mathrm{MWh} \text {. } \\
\text { Rainwater harvested per } \\
\text { year }-150 \mathrm{~m}^{3} \cdot \mathrm{ac}^{-} 1 \cdot \mathrm{a}^{-1} \text {. } \\
\text { Income from crops. }\end{array}$ \\
\hline $\begin{array}{l}\text { Benbol } \\
\text { Wadel } \\
\text { Cornw }\end{array}$ & $\begin{array}{l}\text { PVPP and geese } \\
\text { [7] }\end{array}$ & $\begin{array}{r}\text { Land } \\
\text { power } \\
\text { inst }\end{array}$ & $\begin{array}{l}\text { Elect } \\
\text { Grass } \\
\text { No n }\end{array}$ \\
\hline $\begin{array}{r}\mathrm{Ne} \\
\mathrm{Axn} \\
\mathrm{Un}\end{array}$ & $\begin{array}{c}\text { PVPP and sheep } \\
\text { [7] }\end{array}$ & & \\
\hline $\begin{array}{c}\text { Tsukuba, Ibaraki, } \\
\text { Japan }\end{array}$ & $\begin{array}{l}\text { PVPP, goats and } \\
\text { chickens } \\
{[2]}\end{array}$ & $\begin{array}{c}\text { Land area }-0.1 \mathrm{ha}, \\
\text { PV power plant }-41 \mathrm{~kW}, \\
\text { installed in } 2014, \\
\text { Shading rate }-3 \%\end{array}$ & $\begin{array}{c}\text { Electric energy produced } \\
\text { per year - about } 45 \mathrm{MWh} \\
\text { for the farm. Grass for } \\
\text { chicken and goats. }\end{array}$ \\
\hline $\begin{array}{l}\text { Princeton university } \\
\text { solar field, New } \\
\text { Jersey, United } \\
\text { States of America }\end{array}$ & $\begin{array}{l}\text { PVPP and sheep } \\
{[8]}\end{array}$ & $\begin{array}{l}\text { Land area }-27 \text { ac }(11 \mathrm{ha}) \text {, } \\
\text { PV power plant }-4.5 \mathrm{MW} \text {, } \\
\text { installed in } 2011 . \text { A herd of } \\
75 \text { sheep settled in the solar } \\
\text { field in } 2018 .\end{array}$ & $\begin{array}{l}\text { Electricity - for the } \\
\text { Princeton university. Grass } \\
\text { for a herd of sheep. No } \\
\text { need to cut the grass and } \\
\text { weeds or to use herbicides. }\end{array}$ \\
\hline $\begin{array}{l}\text { Heggelbach, } \\
\text { Region Bodensee- } \\
\text { Oberschwaben, } \\
\text { Germany }\end{array}$ & $\begin{array}{c}\text { PVPP and potatoes } \\
{[2 ; 9]}\end{array}$ & $\begin{array}{l}\text { Experimental area }-1 \mathrm{ha} . \\
\text { PV array }-194.4 \mathrm{~kW} . \\
\text { Efficiency for potatoes - } \\
103 \% \text {, for power }-83 \% \text {. }\end{array}$ & $\begin{array}{l}\text { Electricity - for the farm } \\
\text { needs. Potato harvest can } \\
\text { be sold, and lower quality } \\
\text { can be fed to farm cattle. }\end{array}$ \\
\hline $\begin{array}{l}\text { Bolton Bees, St. } \\
\text { Paul, Minnesota, } \\
\text { United States of } \\
\text { America }\end{array}$ & $\begin{array}{l}\text { PVPP and beehives } \\
\text { [10 ] }\end{array}$ & $\begin{array}{c}\text { 3 PV array sites: } \\
1.2 \mathrm{ac}+40 \mathrm{ac}+40 \mathrm{ac} . \\
\text { Honey extracted per year }- \\
\text { up to } 4000 \mathrm{lb}(1814 \mathrm{~kg}) \text {. }\end{array}$ & $\begin{array}{l}\text { Honey and protection of } \\
\text { bees; preservation of plant } \\
\text { species; better crop yields } \\
\text { due to the pollination. }\end{array}$ \\
\hline
\end{tabular}

Beekeepers also can easily install PV array with the normal density and usual elevation of solar modules in their apiary, to place the rest components of the solar power plant in a metal cabinet or in a nearby building, and to plant the surrounding land with long-blooming honeyed flowers. Such APVS with apiary already operate in Bolton Bees, St. Paul, Minnesota, USA [10], and elsewhere. 
There are no major problems for installations of APVS in fisheries that have sufficiently large bodies of water for shrimps and fish breeding, too. Floating PV arrays can be installed on the fishery's water body and connected by cables to the rest part of the PV power plant. After this, the fish breeding business can be continued along with generating electricity in the own solar power plant $[2 ; 11]$.

A review of the researches described in scientific articles showed that the development of APVS requires consideration of crop tolerance for shade, the height of the PV modules elevation, the distance between the rows (strings) of PV modules, the size of the agricultural machinery, the expediency of rainwater collection from the PV modules, the ways of crop irrigation and fertilizer usage and other factors. Highly efficient water-saving crop irrigation systems through the capillaries are widely used in Israel. In this case, the plants are fed by water along with fertilizer directly through the plant roots. Such irrigation systems could also be applied to APVS. The distance between the strings of PV modules should be chosen according to the degree of tolerance of the crop to the shadows. Crops have to receive the optimum amount of solar energy. High supports are also useful for better homogenizing crop lighting. Different requirements must be met when developing APVS for livestock, poultry, bees, greenhouses, or fisheries. The cases when 2-3 types of fauna (e.g., sheep, chickens, and bees) are kept in the same APVS could be researched, too. Harmonization of all requirements is important as well.

With regard to APVS, a number of important facts need to be mentioned about the key component of these systems, namely, about the permanent progress and current state-of-art of solar power plants. First of all, PVPP, as well as other power plants based on renewable energy sources and nuclear power plants, has a huge superiority against technologies based on fossil fuels because of the very low carbon intensity of power generation measured in grams of $\mathrm{CO} 2$ equivalent per $\mathrm{kWh}(\mathrm{g} \mathrm{CO} 2$ eq per $\mathrm{kWh})$. The average carbon intensity of power generation by technologies is shown in Fig. 1 [12]. The carbon intensity of PVPP is decreasing as the improvement of PV cells leads to less energy consumption.

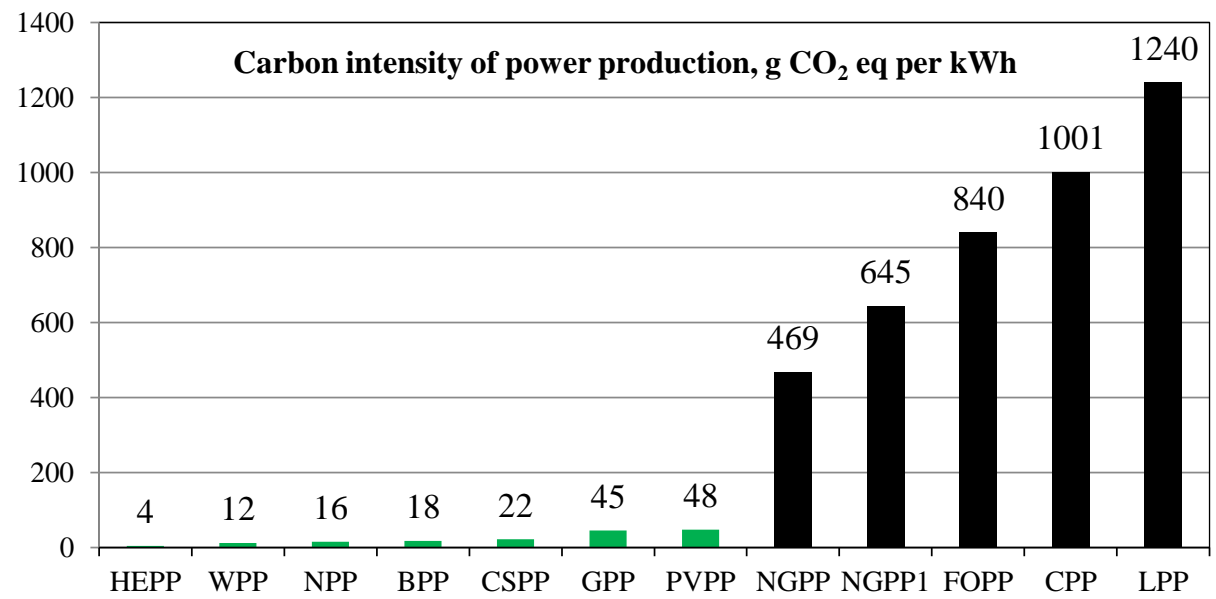

Fig. 1. Average carbon intensity of power generation by the technologies [12]:

HEPP - hydroelectric power plants, WPP - wind power plants, NPP - nuclear power plants, BPP biomass-based power plants, CSPP - concentrated solar power plants, GPP - geothermal power plants, PVPP - photovoltaic power plants, NGPP - power plants running on high quality natural gas, NGPP1 - power plants running on worse quality natural gas, FOPP - power plants running on fuel oil, $\mathrm{CPP}$ - coal-based power plants, and LPP - lignite-based power plants

The first PV modules were developed in the USA. They were used only to generate electricity for satellites and space stations because they were very expensive. At first, no one thought that PV modules would be used on the ground as well, that PVPP would be so powerful, and that the electricity they produced would be so cheap. But thanks to the perseverant work of scientists, all this has been achieved. Key parameters of the main power generation technologies, such as levelized cost of electricity (2020) [13] and full global operating capacity (2019 and prediction up to 2025) [3] together with the evolution of the price index of crystalline silicon PV modules for years 1975-2020 [14] are presented in Table 2. Predictions for the NPP global capacity in the 1970s varied between 2910 and $5300 \mathrm{GW}$ but in reality, only $350 \mathrm{GW}$ were operating in 2000 and $370 \mathrm{GW}$ in 2019 [15]. 
Levelized cost of electricity (LCOE) includes the cost of power plant construction, on-going fuel costs, operating and maintenance costs over its lifetime, and cost of the power plant decommissioning. A 528.5-fold decrease of the price index of PV modules dramatically reduced the LCOE of PVPPs. The LCOE of PVPP and wind power plants (WPP) now has the lowest values in the world, so their common global capacity (PVPP + WPP) is projected to have the fastest growth - from 4th place in 2019, they both will rise to the 1st place in 2025. Many countries around the world have set ambitious goals in the field of PVPP. Already in 2020, the total capacity of all PVPP installed in the world was $132 \mathrm{GW}$ per year, and the target for 2021 is $194 \mathrm{GW}$ [16]. The world's most powerful PVPP of $10 \mathrm{GW}$ is being built in northern Australia to meet Singapore's energy needs [17]. Meanwhile, the world's largest NPP operating in Kashiwazaki-Kariwa, Japan has a net capacity of 7.965 GW [18]. The data presented show that PVPPs are a viable source of energy for the future.

Comparison of key parameters of the main power generation technologies development and evolution of the price index of crystalline silicon PV modules

\begin{tabular}{|c|c|c|c|c|c|}
\hline \multirow{2}{*}{ Year } & \multicolumn{5}{|c|}{ Levelized cost of electricity, USD per MWh [13] } \\
\cline { 2 - 6 } & PVPP + WPP & HEPP & NGPP & CPP & NPP \\
\hline 2020 & $37(\mathrm{PV}), 40(\mathrm{~W})$ & $50[19]$ & 59 & 112 & $163[13]$ \\
\hline \multicolumn{7}{|c|}{ Full global operating capacity, GW [3] } \\
\hline 2019 & $1226(4)$ & $1305(3)$ & $1788(2)$ & $2124(1)$ & $370[15]$ \\
\hline 2021 & $1583(3)$ & $1350(4)$ & $1853(2)$ & $2139(1)$ & No data \\
\hline 2023 & $1953(2)$ & $1398(4)$ & $1935(3)$ & $2132(1)$ & No data \\
\hline 2025 & $2349(1)$ & $1427(4)$ & $1999(3)$ & $2079(2)$ & No data \\
\hline \multicolumn{7}{|c|}{ Evolution of the price index of crystalline silicon PV modules, } \\
\hline 1975 & 1980 & 1990 & 2000 & 2010 & 2020 \\
\hline 105.7 & 29.3 & 7.9 & 4.9 & 2.0 & 0.2 \\
\hline
\end{tabular}

Therefore, many PVPPs are intended to be installed globally for power needs of agriculture. Israeli government decided to combine agriculture and electricity generation, too. Recently they adopted a plan, which anticipates a striking increase of the PV power generation by installation of APVS. The goal of this huge project is to have $15 \mathrm{GW}$ total electric power capacity from the APVS by 2030 [20].

Seeing a very successful development of solar power plants around the world, it is safe to predict that development of APVS will also be successful. In 2020, the highly successful first World Congress AgriVoltaics 2020 took place online. The congress was attended by 350 participants from 38 countries around the world. The next World Congress AgriVoltaics 2021 will be held in June 14-16 (online).

\section{Conclusions}

1. The very successful development of PVPP has led to the development of APVS.

2. The review allows predicting that rapid development of APVS will be efficient and successful.

3. Global studies show that implementation of APVS increases the land use efficiency by up to $186 \%$.

4. Leading countries around the world are in a hurry to reap the benefits of APVS by investing billions of euros to provide a new low-cost multi gigawatt power of electricity.

\section{References}

[1] Goetzberger A. and Zastrow A. On the Coexistence of Solar-Energy Conversion and Plant Cultivation. International Journal of Solar Energy, vol. 1, is. 1, 1982, pp. 55-69. Available at: http://DOI:10.1080/01425918208909875

[2] Brohm R., Khanh N. Q. Dual-use Approaches for Solar Energy and Food Production: International Experience and Potentials for Viet Nam. Hanoi, September 2018. 88 p. Available at: http://rainerbrohm.de/wp-content/uploads/2019/02/Dual-use-approaches-for-solar-energy-and-foodproduction-international-experience_en.pdf

[3] Renewables 2020. Analysis and forecast to 2025. Report. Paris, International Energy Agency, November 2020. 172 p. Available at: https://www.iea.org/reports/renewables-2020 
[4] Kadowaki M., Yano A., Ishizu F. etc. Effects of greenhouse photovoltaic array shading on Welsh onion growth. Biosystems Engineering, vol. 111, 2012, pp. 290-297. Available at: https://www.sciencedirect.com/science/article/pii/S1537511011002273

[5] Ezzaeria K., Fatnassib H., R. Bouharroudc ect. The effect of PV panels on the microclimate and on the tomato production under photovoltaic canarian greenhouses. Solar Energy, vol. 173, 2018, pp. 1126-1134. Available at: https://doi.org/10.1016/j.solener.2018.08.043

[6] Santra P., Singh R. K., Meena H. M. ect. Agri-voltaic system: crop production and PV-based electricity generation from a single land unit. Indian Farming, vol. 68, is. 01, 2018, pp. 20-23.

[7] Agricultural Guidance for Solar Farms. Ed. Dr. Scurlock J. BRE, UK, 2014. 8 p. Available at: https://www.bre.co.uk/filelibrary/nsc/Documents\%20Library/NSC\%20Publications/NSC_Guid_Agricultural-good-practice-for-SFs_0914.pdf

[8] Aronson E. June 28, 2018. "Sheep shear maintenance at Princeton's solar field". [online] [08.02.2021]. Available at: https://www.princeton.edu/news/2018/06/28/sheep-shear-maintenanceprincetons-solar-field

[9] Press Release "Agrophotovoltaics: High Harvesting Yield in Hot Summer of 2018". [online] [15.01.2021] Fraunhofer Institute for Solar Energy Systems. April 12, 2019, 3 p. Available at: https://www.ise.fraunhofer.de/en/press-media/press-releases/2019/agrophotovoltaics-hightharvesting-yield-in-hot-summer-of-2018.html

[10] Amelinckx A. "Solar Power and Honey Bees Make a Sweet Combo in Minnesota" [Online] [24.01.2021]. Weekly Newsletter Modern Farmer, Sep. 01, 2017. Available at: https://modernfarmer.com/2017/09/solar-honey-in-minnesota/?utm_source = solar-power-andhoney-bees\&utm_medium $=$ smithsonian\&utm_campaign $=$ partner

[11]Xue J. Photovoltaic agriculture - New opportunity for photovoltaic applications in China. Renewable and Sustainable Energy Reviews, vol. 73, 2017, pp. 1-9. Available at: http://dx.doi.org/10.1016/j.rser.2017.01.098

[12] Adomavicius V., Kaminickas M. Analysis of PV power future development possibilities. Energetika, vol. 60, issue 4, 2014, pp. 233-248. Available online: https://www.researchgate.net/publication/271836686_Analysis_of_PV_power_future_developme nt_possibilities

[13] Energy matters to climate change. Carroll D. "Biden plans to fight climate change in a way no U.S. president has done before" [online] [05.02.2021]. Available at: https://www.e$\mathrm{mc} 2 . \mathrm{gr} / \mathrm{el} / \mathrm{news} / \mathrm{biden}$-plans-fight-climate-change-way-no-us-president-has-done

[14] International Energy Agency. "Evolution of solar PV module cost by data source, 1970-2020". [online] [25.01.2021]. IEA, Paris. https://www.iea.org/data-and-statistics/charts/evolution-ofsolar-pv-module-cost-by-data-source-1970-2020

[15] Schneider J., Froggatt A., Hareman J. etc. The World Nuclear Industry Status Report 2019. Technical Report. Paris, Budapest: September 2019. 323 p. Available at: https://www.researchgate.net/publication/336870789_The_World_Nuclear_Industry_Status_Repo rt_2019/link/5db7f69f92851c8180121201/download

[16] Hall M. "Jenny Chase predicts up to $194 \mathrm{GW}$ of solar this year". [online] [25.01.2021]. Available at: https://www.pv-magazine.com/2021/01/20/jenny-chase-predicts-up-to-194-gw-of-solar-thisyear/

[17] Carroll D. "Major milestone for world's biggest solar project". [online] [30.01.2021]. Available at: https://www.pv-magazine.com/2021/01/29/major-milestone-for-worlds-biggest-solar-project/

[18] Power Technology Magazine. "Top ten nuclear power plants by capacity". [online] [27.01.2021]. Available at: https://www.power-technology.com/features/feature-largest-nuclear-power-plantsworld/

[19] Company Statista. "Levelized cost of electricity (LCOE) of hydropower worldwide from 2010 to 2019". [online] [05.02.2021]. Available at: https://www.statista.com/statistics/799349/lcoe-ofhydropower-worldwide/

[20] Bellini E. "Israeli government wants to boost development of agrivoltaics". [online] [02.02.2021]. Available at: https://www.pv-magazine.com/2021/02/01/israeli-government-wants-to-boostdevelopment-of-agrivoltaics/ 